\title{
CRITICAL LITERATURE REVIEW ON TAX AVOIDANCE
}

\section{Petr Procházkaa}

\section{Cobham, A., Janský, P.: Estimating Illicit Financial Flows:} A Critical Guide to the Data, Methodologies and Findings

Oxford: Oxford University Press, 2020. ISBN: 9780198854418, https://doi.org/10.1093/ oso/9780198854418.001.0001

\section{Executive Summary}

Illicit financial flows (IFF), be it unlawful or morally unacceptable, are distorting global economy, reducing government tax revenue and rule of law, with a particular impact on developing economies. International tax planning of multinational corporations and wealthy individuals are way ahead of the normative system and the existing indicators to monitor their tax behaviour are not satisfactory, so they should be improved. These two sentences would summarise the main argument that Alex Cobham and Petr Janský are putting forward in their recent work. The objectives of the book (page 23) are to select the best estimates and prioritise the existing approaches. For each of the approaches, data, methodology and results are compared and evaluated. At the end, non-scale and scale IFF indicators are reviewed. Two main indicators are highlighted.

Estimating Illicit Financial Flows: A Critical Guide to the Data, Methodologies, and Findings is a critical literature review in the fields of public finance, taxation, tax evasion, tax avoidance and international tax planning of transnational corporations with an important overlap to development studies. Its authors are Alex Cobham and Petr Janský. The book was published by Oxford University Press in January 2020 as opensource thanks to Tax Justice Network (TJN) sponsorship. This article is a book review that follows the guidelines of Lee et al. (2010).

According to the authors, we are in a state where research into illicit financial flows is increasing in volume and scope as data improve. The main outcome of their work is

a Prague University of Economics and Business, Faculty of International Relations,

Department of International Business, Prague, Czech republic

Email: petr.prochazka@vse.cz, peprochazka@gmail.com 
two-fold. Firstly, they provide an overview and structuring of the existing studies when it comes to any international financial flows that could be deemed as "illicit" (which is a wider term than "illegal"). Secondly, they make a proposal for two indicators that would enable researchers to measure the progress towards sustainable development goal (SDG) 16.4, which says "By 2030, significantly reduce illicit financial and arms flows, strengthen the recovery and return of stolen assets and combat all forms of organised crime". These two indicators are (1) a cross-border profit misalignment measure and (2) the level of undeclared offshore assets. Their ultimate goal is to fight tax evasion and provide a fair share of tax for the jurisdiction where economic activity takes place.

The goal of this review is to present the work to readers in Central and Eastern Europe with economics background. Furthermore, some additional ramifications for future research are offered so that potential researchers know on which areas to focus.

\section{Results}

For readers with a tax background, it is interesting to see a clear classification of tax planning based on Picciotto (2018): illegal tax evasion, unlawful avoidance and lawful avoidance. Missing tax revenue starts a vicious cycle leading to poor governance and lower human security. The roles of taxes are revenue, representation/rule of law, redistribution and repricing.

\section{Trade estimates}

Trade estimates exploit data at the national level (export vs. import accounts, overinvoicing vs. under-invoicing), commodity level (abnormal prices) or transaction level (which truly represent the imbalance but only a limited coverage is available). All in all, the data coverage of these methods is limited in terms of geography and commodity, the classification is too broad or inconsistent and the methods are over-simplified. In general, the authors do not recommend trade estimates as robust measures.

\section{Undeclared offshore assets}

As a pillar resource for capital accounts, Global Financial Integrity (GFI) research is used - Ndikumana and Boyce (1998) quantify the capital flight, GFI measures balance of payment leakages and Henry (2016) provides four methods to come to interesting conclusions; however, all of them have a very general approach with many assumptions, coefficients and multipliers, like his headline "offshore portfolio model". Zucman (2015) has also provided good methodology for covering undeclared wealth and Cobham with Janský emphasise its value. 


\section{International tax planning, profit shifting}

When it comes to profit shifting by transnational corporations, it is a phenomenon close to the border of immoral and unlawful but biggest in scale - up to $40 \%$ of profit is shifted, according to Tørsløv et al. (2020) - compared to pure corruption and misuse of power and public resources in LDCs (Baker, 2005). Also, it is deemed as a relatively new phenomenon basically taking off from the 1990s, with a special hike after the financial crisis. Authors pinpoint several resources by the UNCTAD, IMF and OECD. Clausing (2016) and Zucman (2014) both showed reasons why it is good policy consensus to tax where economic value is created. In the end, Cobham and Janský become proponents of an entirely new approach based on country-by-country reporting, which is one of the OECD (2015) BEPS Project (Action 13) standards that has been applied by more than 100 jurisdictions and is further supported by automatic exchange of information.

\section{Proposals for measures of IFF}

Until all exemptions are removed, there will still be opportunities for Base erosion and profit shifting (BEPS) - until then, substitution of techniques will take place, only leading to decreasing effective tax rates (p. 87). When it comes to successful measures of combating IFF (which were the contents of the previous chapters), Cobham and Janský remember the TJN “ABC" panacea (page 132) that needs to be followed.

1. Automatic exchange of information - reducing impact of non-cooperative "tax havens" and reducing hybrid mismatches as defined by OECD (2015);

2. Beneficial ownership - reducing the extent of banking secrecy and identifying the true beneficiaries of opaque entities;

3. Country-by-country reporting - reducing the benefits from cross-border arrangements by transnational corporations and bringing them to the same level as single-country entities (bigger players are more capable of avoiding tax).

Authors then note some less successful non-scale measures, such as the Financial Secrecy Index (FSI), listing arbitrarily selected tax havens, further developed into Bilateral FSIs, which gets its source in automatic exchange of information; and IFF vulnerability measures such as risk assessment. However, they see potential in a clearcut, robust, measurable scale with reliable and globally available data. They propose two indicators that could be used as SDG measures: (1) misaligned profit and (2) undeclared offshore assets. Both are supposed to serve as a proxy to the IFF, which are immeasurable. 


\section{Evaluation and Future Research}

The clarity of the proposed measures needs to be commended; however, the "misaligned profit" indicator has limited validity. The misalignment is measured as a comparison between profit and a employee count and sales. Thus, entities that show no misalignment would need to have the same labour productivity (i.e., salary) and margin (i.e., profit rate) across all jurisdictions. Unfortunately, this is a generalization that is far from economic reality and far from acceptable. Pure optimization is not distinguished from immoral/illicit behaviour (transfer mispricing, distortion of asset prices, debt shifting, IP mislocalization).

Also, their focus is especially on developing countries, as the proportion of esti-mated tax loss is the highest and impact on population welfare is riskiest there. However, from the global economy point of view, research should focus more on "large" transactions, which are most likely to happen between highly integrated, developed economies. In my personal opinion, some of the approaches do not necessarily correlate with IFF - especially the measure of offshore wealth which is used as a proxy. On page 79, this concern is ad- dressed but no solid grounds for the statement are presented: "Wealth held in tax havens is a direct consequence of some of the illicit financial flows heading from onshore to offshore."

To name some general drawbacks: firstly, the work in itself is a macro-level study from a tax authority standpoint that does not dive deep into real actions of transnational corporations and their causes; it does not discuss which proportion of the allegedly "illicit" is truly motivated by tax avoidance and which only reflects the business needs (as mentioned in Procházka, forthcoming 2020). In this respect, more insights from the business and microlevel perspective are needed to better understand what is behind the global numbers on tax avoidance or effective tax rates. Secondly, the inclusion of the offshore assets indicator should have been better elaborated and defended. Last but not least, despite criticising the arbitrary use of "tax havens", authors widely use the term across the whole publication - this fact being the evidence that a further elaboration of the BFSI should be supported, as on $\mathrm{p} .100$ it is mentioned that a "tax haven" is any jurisdiction with a tax differential.

Among the benefits of the review, I have to highlight a very clear structure, use of standardised formulas and comparison of results that are maintained for all the analysed approaches to easily compare with each other. They did select the best estimates and prioritise existing approaches (those were their goals), but a pre-selection of studies and authors was certainly in place. Despite providing 244 references (32 of them have been authored or co-authored by either Cobham, Janský or both), such a broad topic will always require certain limitation in the scope. From older research in development economics, only Bhagwati was cited, but other relevant sources were omitted. To list Nobel Prize winners only, no reference was made to tax avoidance analysis by Joseph Stiglitz (1985), 
financial transactions and Tobin tax, Amartya Sen and his capability theory, Paul Krugman and New Economic Theory. No business finance, accounting or management scholars were mentioned (as reviewed by Wang et al., 2019). Also worth noting, determinants of tax avoidance were little discussed (mention of Hines and Rice, 1994). From recent global efforts, impact on BEPS 2.0 could have been analysed more deeply. Of course, these omissions are understandable due to the limited length and particular focus of the review but could bring further ways to develop the research.

\section{Implications and Conclusions}

This critical literature review is a logical outcome of the common quest by Alex Cobham and Petr Janský in the field of public finance and development economics when it comes to illicit financial flows and fair taxation. Both connected with Oxford University, they worked at the same time in Christian Aid in 2011-2012, Centre for Global Development in 2013 and ActionAid in 2017-2018. Since 2014, they have published at least 11 articles together and participated in at least 2 research grants. Their review is in itself also a review of their common research trajectory and achievements.

As the authors admit, ways of IFF are immense and widely exploited, whereas ways to estimate and monitor these are limited and still lagging behind, e.g., when it comes to trade estimates (lack of trade in services, or proper analysis of intangibles). They correctly identify the whole situation as constantly changing in both the economic reality and normative responses by authorities, and they deem their book as "an attempt to hit a moving target" (page viii). In my eyes, they have created a successful framework fir evaluating existing measures and new research that is yet to come. The proposed indicators for SDG 16.4 are probably the best that can be constructed at the moment, but should be reviewed and improved as availability and quality of data increases over time. Importantly, using any indicator will always bring us to an underestimation of reality, as many transactions are hidden from statistics.

Apart from establishing two measurable SDG 16.4 indicators, we can see a series of important advances. One of them is the use of a "group approach" (page 87), as opposed to the traditional parent-subsidiary relationship as anchored in most legislations. Calling for a more efficient information exchange and "lean" and digitalised administration goes hand in hand. Also, Cobham and Janský recommend taxing rights to be monitored and information to be collected at the UN level, not with standards for partial enforcement (OECD) or regionally valid (EU). All in all, they (like me) lean towards creating one simple and transparent global tax system with global enforcement, no inefficiencies and no room for speculation. 


\section{References}

Baker, R. W. (2005). Capitalism's Achilles Heel: Dirty Money and How to Renew the Free-market System. Wiley. ISBN 1119086612.

Clausing, K. A. (2016). The Effect of Profit Shifting on the Corporate Tax Base in the United States and Beyond. National Tax Journal, 69(4), 905-934, https://doi.org/10.17310/ ntj.2016.4.09

Cobham, A., Janský, P. (2020). Estimating Illicit Financial Flows: A Critical Guide to the Data, Methodologies, and Findings. Oxford: Oxford University Press, https://doi.org/10.1093/ oso/9780198854418.001.0001

Henry, J. S. (2016). More than $\$ 12$ Trillion Stuffed Offshore, from Developing Countries Alone. Chesham: Tax Justice Network.

Hines, J. R., Rice, E. M. (1994). Fiscal Paradise: Foreign Tax Havens and American Business. The Quarterly Journal of Economics, 109(1), 149-182, https://doi.org/10.2307/2118431

Lee, A. D., Green, B. N., Johnson, C. D., et al. (2010). How to Write a Scholarly Book Review in a Peer-reviewed Journal: A Review of the Literature. The Journal of Chiropractic Education, 24(1), 57-69, https://doi.org/10.7899/1042-5055-24.1.57

Ndikumana, L., Boyce, J. (1998). Congo's Odious Debt: External Borrowing and Capital Flight in Zaire. Development and Change, 29(2), 195-217, https://doi.org/10.1111/14677660.00076

OECD (2015). OECD/G20 Base Erosion and Profit Shifting Project 2015 Final Reports. Executive Summaries. Paris: OECD.[Retrieved 2019-01-21] Available at: http://www.oecd.org/ctp/ beps-reports-2015-executive-summaries.pdf

Picciotto, S. (2018). Why Tax Avoidance is Illicit. [Retrieved 2019-05-26] Brighton: The International Centre for Tax and Development (ICTD). Available at: https://www.ictd.ac/ blog/why-tax-avoidance-is-illicit/

Procházka, P. (2020). Stakeholder Contribution to Global Tax Governance: Analysis of Public Comments on OECD/G20 BEPS Action Plan. In.: Helísek, M. (2020). Prezentace výsledků ekonomického a finančního výzkumu doktorandů. Vysoká škola finanční a správní, Praha. ISBN 978-80-7408-217-8.

Stiglitz, J. E. (1985). The General Theory of Tax Avoidance. National Tax Journal, 38(3), 325-338.

Tørsløv, T. R., Wier, L., Zucman, G. (2020). Externalities in International Tax Enforcement: Theory and Evidence. National Bureau of Economic Research. Cambridge, MA Working Paper No. 26899, https://doi.org/10.3386/w26899

Wang, F., Xu, S., Sun, J., et al. (2020), Corporate Tax Avoidance: A Literature Review and Research Agenda. Journal of Economic Surveys, 34(4), 793-811, https://doi.org/10.1111/ joes. 12347

Zucman, G. (2014). Taxing Across Borders: Tracking Personal Wealth and Corporate Profits. Journal of Economic Perspectives, 28(4), 121-148, https://doi.org/10.1257/jep.28.4.121

Zucman, G. (2015). The Hidden Wealth of Nations: The Scourge of Tax Havens. Chicago: University of Chicago Press. ISB 978-0226245423. 